\title{
Effect of freeze, hot-air, and vacuum drying on antioxidant properties and quality characteristics of samnamul (Aruncus dioicus var. kamtschaticus)
}

\author{
Ah-Na Kim ${ }^{1}$, Kyo-Yeon Lee ${ }^{1}$, Myeong-Hwa $\mathrm{Ha}^{2}$, Ho Jin $\mathrm{Heo}^{1,3}$, Sung-Gil Choi ${ }^{1,3 *}$ \\ ${ }^{1}$ Division of Applied Life Science, Gyeongsang National University, Jinju 52828, Korea \\ ${ }^{2}$ Division of the Support and Planning, Gyeongsangnam-do Agricultural Research and Extension Services, Jinju 52733, Korea \\ ${ }^{3}$ Division of Food Science and Technology (Institute of Agriculture and Life Scieces), \\ Gyeongsang National University, Jinju 52828, Korea
}

\section{열풍, 진공 및 동결건조가 눈개승마의 항산화 및 품질특성에 미치는 영향}

\author{
김아나 ${ }^{1} \cdot$ 이교연 ${ }^{1} \cdot$ 하명화 $^{2} \cdot$ 허호진 $^{1,3} \cdot$ 최성길 ${ }^{1,3 *}$ \\ ${ }^{1}$ 경상대학교 응용생명과학부 응용생명과학전공, ${ }^{2}$ 경상남도농업기술원 지원기획과, \\ 3경상대학교 농화학식품공학과(농업생명과학연구원)
}

\begin{abstract}
The purpose of this study was to evaluate the effect of drying methods including freeze, hot-air, and vacuum drying on the nutritional properties, antioxidant activities, and drying properties of Aruncus dioicus var. kamtschaticus. The optimum temperature of hot-air drying was $100^{\circ} \mathrm{C}$ based on the total phenolic and flavonoid content and antioxidant activities, which were altered as a function of drying temperatures of $60,80,100$, and $120^{\circ} \mathrm{C}$. In addition, based on the drying curve, the optimum condition of hot-air and vacuum drying was $100^{\circ} \mathrm{C}$ for $10 \mathrm{~min}$, whereas that of freeze drying was 210 min. Vacuum drying was most effective for removal of moisture compared with the other drying methods. The water activity and water solubility index of dried samples obtained by the different drying methods were not significantly different. The water absorption index and rehydration ratio increased in the order of freeze, vacuum, and hot-air drying because of differences in porous structure of $A$. dioicus. Thus, vacuum drying of $A$. dioicus leads to the highest total phenolic and flavonoid content and antioxidant activities, followed by hot-air, and freeze drying.
\end{abstract}

Key words : Aruncus dioicus var. kamtschaticus, samnamul, vacuum drying, hot-air drying, freeze drying

\section{서 론}

눈개승마(Aruncus dioicus var. kamtschaticus)는 삼나물이 라고도 하며 쌍떡잎식물 장미목 장미과(Rosaceae)의 다년 생 초본식물로 한국, 일본 및 중국의 고산 수림지대에 분포 하는 대표적인 산채자원으로 알려져 있다(1). 눈개승마는

*Corresponding author. E-mail : sgchoi@gnu.ac.kr Phone : ※ 개인정보 표시제한 Fax : 82-55-772-1909

Received 5 September 2018; Revised 11 October 2018; Accepted 12 October 2018.

Copyright (c) The Korean Society of Food Preservation. All rights reserved.
식재후 10 년 이상 장기 생육이 가능한 고소득의 순채로서 독특한 향기와 상큼한 맛으로 인한 높은 기호성과 더불어 우수한 건강기능성이 보고됨에 따라 소비자의 관심이 증가 하고 있다(1). 또한 눈개승마는 식이섬유, 무기성분, 페놀성 화합물, monoterpenoids 등이 다량 함유되어 있으며, 이에 따라 항산화(2), 항노화(3), 면역증진(4), 당뇨 및 고지혈증 완화(5), 주름개선 효과(1) 등의 다양한 약리학적 가치가 보고되고 있어 건강지향식품 소재로 부각되고 있다.

눈개승마를 포함한 대부분의 산채식물들은 생산시기가 한정되어 있어 가용시기가 제한적이고 높은 수분함량으로 미생물의 생육, 생화학적 변화, 화학반응이 쉽게 일어나는 문제점이 있으며, 중량에 비해 체적이 크기 때문에 저장 
및 유통에 제한적이다(6). 따라서 이를 건조물로 가공함으 로써 저장성을 향상시켜 산채식물이 연중 공급될 수 있도록 하고 있으며, 이를 소비자가 분말화하거나 수침으로 복원 시켜 섭취하도록 판매하고 있다(6,7). 식품의 건조는 수분 함량이 많은 식품에서 수분을 제거하여 미생물 및 효소에 의한 부패나 변질을 방지함으로써 식품의 저장성 및 수송성 을 부여하는 수단으로 사용되고 있다(8). 현재 열풍건조가 가장 보편적으로 사용되고 있으며, 이는 균일한 건조와 단 시간의 건조시간으로 경제적이지만, 건조 중의 수축현상과 표면경화 현상, 건조물의 낮은 복원성, 높은 온도와 산화반 응에 의한 영양성분 파괴 및 갈변현상 등이 문제가 되고 있다(9). 따라서 본 연구에서는 이와 같은 문제점을 보완하 기 위하여 최근에 산업적으로 사용되고 있는 동결건조와 진공건조의 건조방법을 열풍건조와 비교하여 연구하였다. 동결건조는 낮은 온도에서 동결된 시료의 승화과정을 통해 진행되어 건조기간이 길며, 진공건조는 비교적 높은 온도 와 낮은 압력 하에서 공정을 진행함으로써 건조속도를 증가 시켜 건조시간이 짧은 것으로 알려져 있다. 두 건조방법 모두 산소 농도가 낮은 진공환경에서 진행되는 공정이기 때문에 복원성이 우수하고, 식품의 산화반응을 제어할 수 있어 기호적 및 영양적 가치를 상대적으로 높게 유지할 수 있는 건조방법으로 알려져 있다(10,11).

현재 농가 및 산업체에서 제조하는 건조 눈개승마는 열 풍건조방법으로 체계적인 처리 조건 없이 가공되고 있기 때문에 생물이 가지는 기호성과 생리활성능이 저하된 상태 로 유통되고 있지만 이러한 문제점을 보완하기 위한 연구는 전무한 실정이다. 따라서 본 연구에서는 열풍, 동결 및 진공 건조를 통해 건조방법을 달리하여 눈개승마의 품질 및 건조 특성에 미치는 영향을 비교·분석하였고, 이에 따라 적합한 건조공정 및 조건을 확립함으로써 고품질의 건조 눈개승마 를 제조하기 위한 기초 자료를 제공하고자 하였다.

\section{재료 및 방법}

\section{실험 재료}

본 실험에 사용한 눈개승마(Aruncus dioicus var. kamtschaticus)는 강원도 태백시에서 위치한 태백쌈채마을 로부터 2017년 4월에 구입하여 줄기를 제거한 후 잎을 이용 하였으며, 외관 상태가 양호하고 중량이 $0.25 \pm 0.01 \mathrm{~g}$ 으로 균일한 것을 선별하였고, 이를 $5^{\circ} \mathrm{C}$ 에서 보관하여 사용하였 다.

\section{건조방법}

눈개승마의 건조방법으로는 동결, 열풍, 진공건조를 실 시하였으며, 최종 건조시간은 피건조물의 수분함량이 더 이상 변화가 없을 때까지 실시하였다. 동결건조는 액체질
소를 이용하여 급속동결한 후 $-80^{\circ} \mathrm{C}$ 에서 48 시간 동안 동결 시켜 동결건조기(FDU-8612, Operon Co., Gimpo, Korea)를 이용하여 $1 \mathrm{kPa}$ 이하에서 30 분 간격으로 180 분간 건조하였 다. 열풍건조의 경우 hot air dry oven(JS-150SP, Jinscience, Gimcheon, Korea)을 이용하였으며, $60,80,100,120^{\circ} \mathrm{C}$ 의 온도에서 건조하였다. 건조시간은 $60,80,100,120^{\circ} \mathrm{C}$ 의 건 조온도에서 각각 6 분 간격으로 54 분, 3 분 간격으로 30 분, 1 분 간격으로 11 분 동안 건조를 실시하였다. 진공건조는 vacuum dry oven(KS-VD-101, Kyongsang Science Co., Seoul, Korea)을 이용하여 $10 \mathrm{kPa}$ 이하에서 실시하였으며, 열풍건조 시 최적 건조온도에서 1 분 간격으로 10 분간 실시 하였다. 건조 눈개승마의 평균 중량은 약 $0.075 \mathrm{~g}$ 으로 나타 났으며, 수분함량, 수분활성도, 수화복원성은 건조물을 사 용하여 분석하였다. 총 페놀 및 플라보노이드 함량, 항산화 활성과 수분용해지수 및 수분흡착지수의 경우에는 약 50 $\mathrm{g}$ 의 건조물을 믹서기(HWF-630WG, Hanil Electric, Wonju, Korea)를 이용하여 30 초간 분쇄한 후 직경 $425 \mu \mathrm{m}$ 체에 거른 분말을 실험에 사용하였다.

\section{수분함량 및 수분활성도}

눈개승마의 수분함량은 $\mathrm{AOAC}$ 법(12)에 따라 상압 가열 건조법에 의하여 측정하였다. 수분활성도는 수분활성도 측 정기(AQS-2, Nagy mess system, Gäufelden, Germany)를 이 용하여 측정하였으며, 증류수 $(\mathrm{Aw}=1.000)$ 를 이용하여 실온 $\left(20^{\circ} \mathrm{C}\right)$ 에서 보정한 후 사용하였다. 건조 눈개승마를 $20^{\circ} \mathrm{C}$ 의 온도를 평형화하였고, 기밀용기에서 평형수분함량에 도달 시킨 후 평형상대습도를 측정하여 수분활성도를 구하였다.

\section{총 페놀 및 플라보노이드 함량 분석}

건조방법에 따른 눈개승마의 총 페놀 함량은 Kim 등(13) 의 방법을 참고 및 수정하여 실험을 진행하였다. 즉, 건조 눈개승마 분말 $0.5 \mathrm{~g}$ 을 $80 \%$ 에탄올로 희석하여 균질기 (D-500, Wiggen Hauser, Berlin, Germany)로 10,000 rpm에서 30 초간 균질한 후 $5^{\circ} \mathrm{C}$ 에서 $200 \mathrm{rpm}$ 으로 추출하였으며, 이를 여과한 여과액을 이용하였다. 여과액 $1 \mathrm{~mL}$ 와 증류수 $9 \mathrm{~mL}$ 을 혼합 후 $1 \mathrm{~mL}$ 의 Folin \& Ciocalteu's phenol reagent를 첨가하여 실온 암실에서 5 분간 방치한다. 그 후 $7 \%$ Sodium carbonate $10 \mathrm{~mL}$ 와 증류수 $4 \mathrm{~mL}$ 을 첨가한 후 실온 암실에서 2시간 방치하였으며, 분광광도계(UV-1800, Shimadzu Corporation, Kyoto, Japan)를 이용하여 $760 \mathrm{~nm}$ 에서 흡광도 를 측정하였다. 표준곡선은 gallic acid를 표준물질로 0.025 , $0.05,0.1,0.25,0.5,1 \mathrm{mg} / \mathrm{mL}$ 로 제조하여 흡광도를 측정하였 으며, 총 페놀 함량은 g gallic acid equivalent(GAE)/kg로 나타내었다.

총 플라보노이드 함량은 $\mathrm{AOAC}$ 에서 공인된 방법을 수정 한 Chae 등(14)의 방법에 따라 분석하였다. 여과액 $0.1 \mathrm{~mL}$ 와 $90 \%$ diethylene glycol $0.9 \mathrm{~mL}$ 를 혼합한 후 $1 \mathrm{~N} \mathrm{NaOH} 20$ 
$\mu \mathrm{L}$ 를 첨가하여 $37^{\circ} \mathrm{C}$ 항온수조에 20 분 동안 반응시켰다. 이를 분광광도계를 이용하여 $420 \mathrm{~nm}$ 에서 흡광도를 측정하 였으며, 총 플라보노이드 함량은 g rutin equivalent(RE) $/ \mathrm{kg}$ 로 나타내었다.

\section{항산화 활성 측정}

건조방법에 따른 눈개승마의 항산화 활성을 측정하기 위해 건조 눈개승마 분말 $0.5 \mathrm{~g}$ 을 $80 \%$ 에탄올로 희석하여 균질기(D-500, Wiggen Hauser, Berlin, Germany)로 10,000 $\mathrm{rpm}$ 에서 30 초간 균질한 후 $5^{\circ} \mathrm{C}$ 에서 $200 \mathrm{rpm}$ 으로 추출하였 으며, 이를 여과한 여과액을 이용하였다. 항산화 활성 분석 법으로는 DPPH 라디컬 소거능, ABTS 라디컬 소거능, FRAP 환원력을 실시하였으며, 모두 g trolox equivalent(TE) $/ \mathrm{kg}$ 으로 나타내었다.

2,2-Diphenyl-1-picrylhydrazyl(DPPH) 라디컬 소거 활성 은 Blois(15)의 방법을 변형하여 실험을 진행하였다. 100 $\mathrm{mL}$ 의 에탄올에 $8 \mathrm{mg}$ 의 DPPH를 용해시켜 제조하였으며, 여과액 $0.1 \mathrm{~mL}$ 를 DPPH 용액(OD:1.000) $0.9 \mathrm{~mL}$ 와 혼합하여 실온 암실에서 30 분간 방치 후 분광광도계를 이용하여 517 $\mathrm{nm}$ 에서 흡광도를 측정하였다.

2,2'-Azino-bis(3-ethylbenzthiazoline-6-sulfonic $\mathrm{acid})$ (ABTS) 라디컬 소거능은 $\mathrm{Re}$ 등(16)의 방법을 변형하 여 실험을 진행하였다. ABTS 용액은 $7 \mathrm{mM}$ ABTS diammonium salt와 $2.45 \mathrm{mM}$ potassium persulphate를 혼합 후 실온 암실에서 16 시간 동안 방치하여 제조하였다. 여과 액 $20 \mu \mathrm{L}$ 와 ABTS 용액 $980 \mu \mathrm{L}$ 를 혼합하여 실온 암실에서 6 분 동안 방치한 후 분광광도계를 이용하여 $734 \mathrm{~nm}$ 에서 흡광도를 측정하였다.

Ferric ion reducing antioxidant power(FRAP) 측정은 Benzie와 Strain(17)의 방법을 변형하여 실험을 진행하였다. 즉 $300 \mathrm{mM}$ sodium acetate buffer(pH 3.6)와 $40 \mathrm{mM} \mathrm{HCl}$ 로 용해시킨 $10 \mathrm{mM}$ trpydyltriazine(TPTZ), $20 \mathrm{mM} \mathrm{FeCl} \cdot 6 \mathrm{H}_{2} \mathrm{O}$ 을 제조하였고, 이를 각각 $10: 1: 1(\mathrm{v} / \mathrm{v} / \mathrm{v})$ 비율로 혼합하여 FRAP 용액을 제조하였다. 여과액 $50 \mu \mathrm{L}$ 와 FRAP 용액 1.5 $\mathrm{mL}$ 를 혼합하였고, 이를 실온 암실에서 30 분간 방치한 후 분광광도계를 이용하여 $593 \mathrm{~nm}$ 에서 흡광도를 측정하였다.

\section{수분용해지수 및 수분흡착지수 측정}

건조방법에 따른 눈개승마의 수용성 성질을 분석하기 위해 수분용해지수 및 수분흡착지수를 AACC방법(18)을 응용하여 측정하였다. 건조 눈개승마 분말 $0.5 \mathrm{~g}$ 을 증류수 $25 \mathrm{~mL}$ 를 가하고 $30^{\circ} \mathrm{C}$ shaking water bath(BS-21, JEIO $\mathrm{TECH}, \mathrm{Kimpo}$, Korea)에서 $200 \mathrm{rpm}$ 에서 30분간 교반한 후 $3,000 \mathrm{rpm}$ 으로 20 분간 원심분리하였다. 원심분리한 상등액 을 $105^{\circ} \mathrm{C}$ 에서 5 시간 건조 후, 30 분간 데시케이터에서 방냉 하여 고형분 함량을 도출하였다. 또한 원심분리 후 상등액 을 제거, 침전물의 무게를 측정하였고 이를 이용하여 수분 용해지수(water soluble index, WSI)와 수분흡착지수(water absorption index, WAI)를 산출하였다.

$$
\text { WSI }(\%)=\frac{\text { dry solid wt. recovered by evaporating the spertanant }(\mathrm{g})}{\text { dry sample wt.(g) }} \times 100
$$

$$
\operatorname{WAI}(\mathrm{g} / \mathrm{g})=\frac{\text { hydrated sample wt.(g)-dry sample wt(g) }}{\text { dry sample wt.(g) }} \times 100
$$

\section{수화복원성}

건조방법에 따른 눈개승마의 수화복원성(rehydration ratio)은 증류수 $100 \mathrm{~mL}$ 가 든 비커를 $30^{\circ} \mathrm{C}$ 항온수조에 넣어 증류수의 온도를 동일하게 하였고, 약 $0.075 \mathrm{~g}$ 의 건조 눈개 승마를 완전히 침지한 다음 1 시간 후에 꺼내어 시료의 표면 의 물기를 10 초간 제거하였고, 증가한 무게를 측정하여 다 음 식에 의해 계산하였다(19).

$$
\mathrm{WAI}(\mathrm{g} / \mathrm{g})=\frac{\text { weight }_{\text {rehydrated sample }}}{\text { weight }_{\text {dried sample }}}
$$

\section{통계 분석}

실험결과는 6회 반복 실험하여 얻어진 평균표준편차로 나타내었고, 통계처리는 Window 용 SAS 9.4 version(v 9.4 version, SAS Institute Inc, Cary, NC, USA)을 이용하여 $\mathrm{p}<0.05$ 수준에서 분산분석(analysis of variance)을 실시하였 으며, Duncan의 다중 범위 검정법(Duncan's multiple range test)으로 유의성을 검증하였다.

\section{결과 및 고찰}

\section{열풍건조 조건에 따른 건조곡선}

열풍건조온도 및 시간에 따른 눈개승마의 수분함량변화 는 Fig. 1 과 같다. 열 풍건조온도는 $60,80,100,120^{\circ} \mathrm{C}$ 에서 실시하였으며, 시료의 수분함량이 변화가 없을 때까지 건 조시간별로 수분함량을 측정하였다. 일반적으로 식품건조 시 피건조물이 기화 온도까지 가열되는 예열 기간과 자유수 면에서 물이 증발하여 건조속도가 가장 빠른 항률 건조기 간, 표면수분이 전부 제거되고 식품내부에 존재하는 수분 이 표면으로 이동되면서 건조되는 감률 건조기간을 거치게 된다(21). 이와 같이 본 연구결과의 건조곡선에서 60,80 , $100^{\circ} \mathrm{C}$ 의 건조온도에서는 예열 기간, 항률 건조기간, 감률 건조기간이 관찰되었으며, $120^{\circ} \mathrm{C}$ 건조의 경우 높은 온도로 인해 예열 기간이 뚜렷하게 나타나지 않은 것으로 사료된 다. 건조온도가 높아질수록 건조속도가 빨라지는 것으로 
나타나 열풍건조온도는 건조속도에 매우 의존적인 것으로 생각된다. 또한 열풍건조온도 $60,80,100,120^{\circ} \mathrm{C}$ 에서 건조 시간이 각각 약 48 분, 27 분, 10 분, 10 분으로 나타났다. 감률 건조기간에 도달하는 건조시간은 $100^{\circ} \mathrm{C}$ 보다 $120^{\circ} \mathrm{C}$ 의 건조 온도에서 더 빠른 것으로 나타났지만 평형수분함량에 도달 하는 시간은 동일한 것으로 나타났다. Rhim과 Hwang(20) 은 건조가 너무 빠르게 진행되어 감률 건조기간 중 표면 건조속도가 내부 수분의 확산속도보다 더 빠를 때 내부에 미처 건조되지 않은 수분이 존재하는 상태에서 건조된 겉껍 질이 형성된 것을 표면경화라고 하며, 그 결과 평형수분함 량에 도달하는 시간이 길어지거나 건조가 중지된다고 보고 하였다.

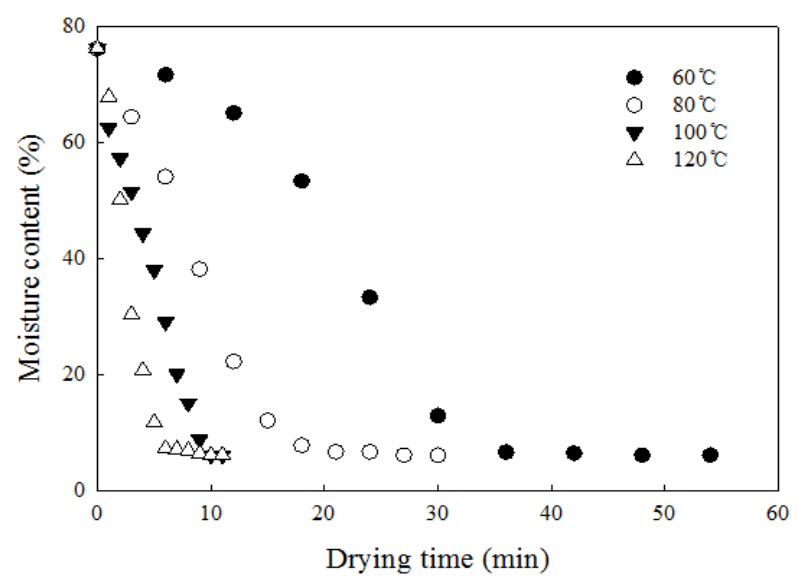

Fig. 1. Changes in moisture content of Aruncus dioicus var. kamtschaticus as a function of air-drying temperatures of 60,80 , 100 , and $120^{\circ} \mathrm{C}$.

\section{열풍건조온도에 따른 총 페놀 및 플라보노이드 함량과 항 산화 활성}

산채식물에 다량 함유되어 있는 폴리페놀 화합물과 플라 보노이드는 높은 항산화 활성을 가짐으로써 우수한 건강기 능성을 부여하는 주요 생리활성물질로 알려져 있다 $(1,21,22)$. 따라서 각 열풍건조온도별 최종 건조시간으로 처리한 건조물의 총 페놀 및 플라보노이드 함량과 항산화 활성을 측정하여 비교하였으며, 그 결과는 Fig. 2 와 같다. $60^{\circ} \mathrm{C}$ 에서 건조한 눈개승마의 총 페놀 함량 및 플라보노이드 함량이 가장 낮은 것으로 나타났으며, 건조온도가 $100^{\circ} \mathrm{C}$ 까 지 증가할수록 그 함량이 증가하여 총 페놀 함량은 85.38 $\mathrm{g} \mathrm{GAE} / \mathrm{kg}$, 총 플라보노이드 함량은 $60.49 \mathrm{~g} \mathrm{RAE} / \mathrm{kg}$ 으로 나타났다. Lee 등(22)은 눈개승마의 잎에 존재하는 총 폴리 페놀 및 플라보노이드 함량은 각각 66.48 과 $16.47 \mathrm{\mu g} / \mathrm{mg}$ 으 로 보고하였으며, Youn 등(1)은 눈개승마의 총 페놀 함량과 총 플라보노이드 함량이 각각 $122.60 \mathrm{mg} / \mathrm{g}$ 과 $36.80 \mathrm{mg} / \mathrm{g}$ 으 로 보고하였다. 눈개승마의 총 페놀 및 플라보노이드 함량 차이는 산채식물의 재배지, 토양성분, 광조건 등의 재배환
경과 채취시기와 추출조건의 차이에 기인한 것으로 생각된 다(23).

열풍건조온도별 눈개승마 건조물의 DPPH 라디컬 소거 능, $\mathrm{ABTS}$ 라디컬 소거능, $\mathrm{FRAP}$ 을 통해 분석한 항산화 활성 결과는 총 페놀 및 플라보노이드 함량 결과와 같이 $60^{\circ} \mathrm{C}$ 에 서 $100^{\circ} \mathrm{C}$ 까지 건조온도가 증가할수록 항산화 활성이 증가 하는 것으로 나타났다. 이러한 결과는 건조온도가 높아질 수록 건조기 내부와 피건조물의 수증기압 차이가 커짐에 따라 건조속도가 빨라져 건조시간이 단축됨으로써 시료가 열과 접촉하는 시간이 줄어들었기 때문으로 생각된다. 또 한 고분자의 페놀성 화합물 및 단백질에 결합한 페놀성 화합물이 열처리에 의해 저분자의 페놀성 화합물로 전환되 거나 이들 간의 결합이 파괴되었기 때문으로 생각된다(24). $\mathrm{Kim}$ 등(25)은 대추의 열처리에 의한 플라보노이드 함량의

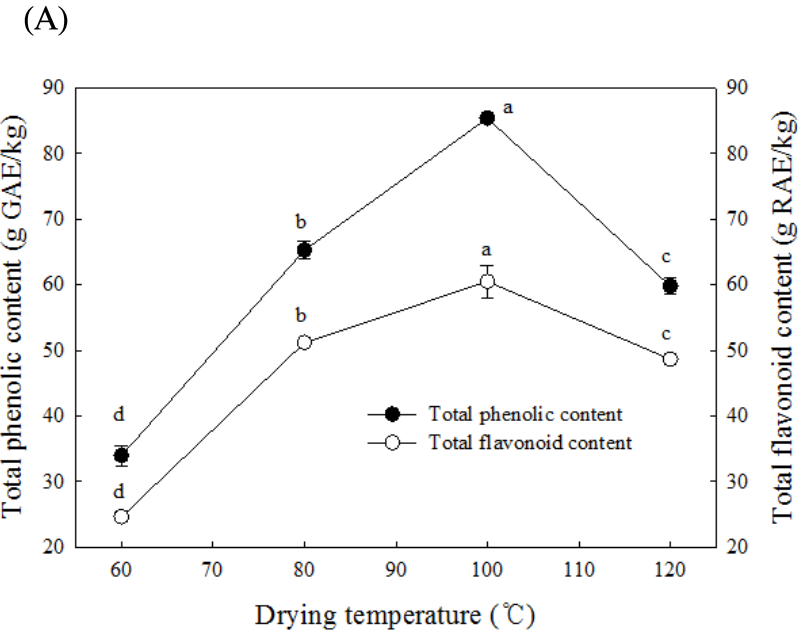

(B)

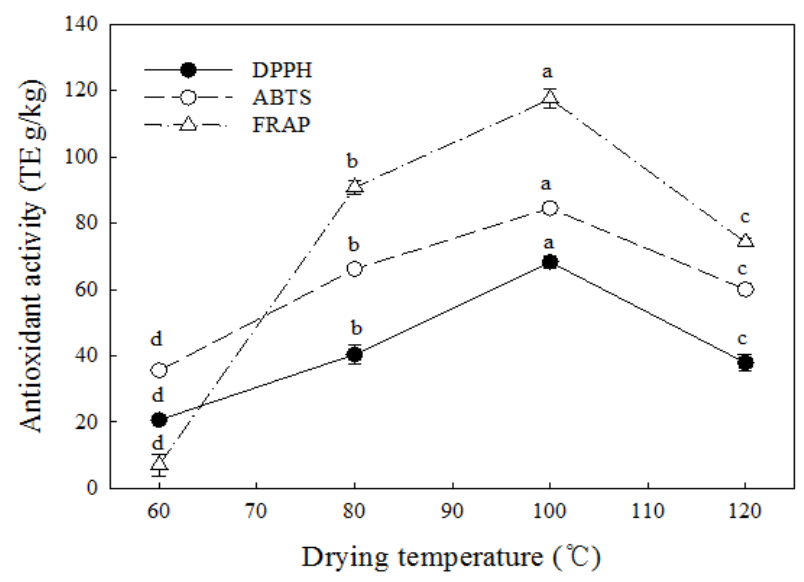

Fig. 2. Total phenolic and flavonoid content (A) and antioxidant activity such as DPPH radical scavenging activity, ABTS radical scavenging activity, and FRAP assay (B) of Aruncus dioicus var. kamtschaticus as a function of air-drying temperatures of 60,80 , 100 , and $120^{\circ} \mathrm{C}$.

Results shown are mean \pm SD $(n=6)$. Different superscripts within the same parameter are significantly different $(\mathrm{p}<0.05)$ by Duncan's test. 
증가는 열에 의한 페놀계 유도체의 가용화가 용이해졌기 때문이라고 보고하였다. 반면, $100^{\circ} \mathrm{C}$ 의 건조온도까지 눈개 승마의 총 페놀 및 플라보노이드 함량과 항산화 활성이 증가하였다가 $120^{\circ} \mathrm{C}$ 의 건조온도에서 함량 및 활성이 급격 히 감소한 것으로 나타났다. Lee 등(26)은 과도한 열처리는 피건조물의 탄화로 인한 품질저하를 일으킬 수 있는데, 특 히 페놀성 화합물 및 플라보노이드가 파괴되어 항산화 활성 이 일부 소실되어 영양적 가치를 감소시킬 수 있다고 보고 하였다. 결과적으로 눈개승마를 열풍건조 시 $100^{\circ} \mathrm{C}$ 에서 건 조하는 것이 영양학적 측면에서 가장 적합할 것으로 생각된 다.

\section{건조방법에 따른 건조곡선}

눈개승마의 건조방법에 따른 수분함량 변화를 측정한 결과는 Fig. 3 과 같다. 열풍건조와 진공건조는 최적 건조온 도인 $100^{\circ} \mathrm{C}$ 에서 실시하였으며, 열풍건조, 진공건조, 동결건 조 시 건조시간은 각각 10 분, 10 분, 210 분으로 나타났고,

(A)

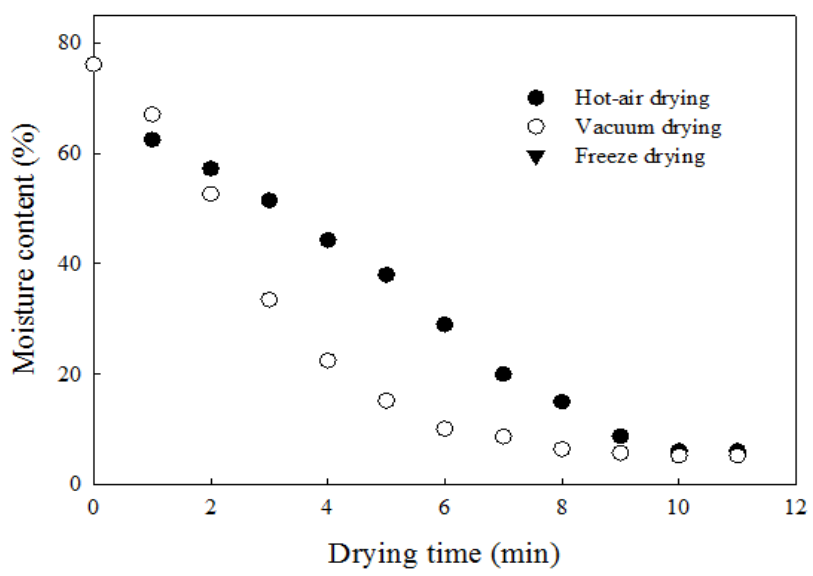

(B)

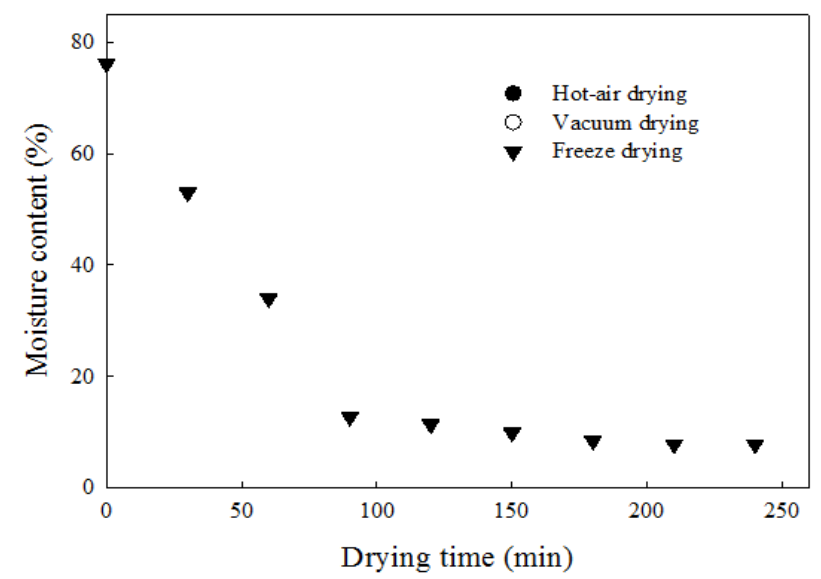

Fig. 3. Changes in moisture content of Aruncus dioicus var. kamtschaticus dried by hot-air drying and vacuum drying at $100^{\circ} \mathrm{C}$ (A) and freeze drying (B) as a function of drying time.
모든 건조방법에서 건조시간이 길어질수록 수분함량이 감 소하는 것으로 나타났다. 진공건조의 건조시간에 따른 수 분함량 경우 지수적인 감소 패턴을 보이는 것으로 나타났으 며, 이는 건조기 내부의 감압에 의해 피건조물 내부와 외부 의 수증기압 차이가 커짐에 따라 초기에 수분함량이 급격히 감소하였고, 이에 따라 내부 수분함량이 적어지면서 수증 기압 차이가 작아져 감소 속도가 줄어든 것으로 생각된다. 동결건조는 건조 90 분까지 시료의 수분함량이 급격히 증가 하였지만 90 분 이후부터 건조속도가 현저히 감소한 것으로 나타났다. 동결건조 시 승화건조는 유리수를 제거하여 총 수분의 65-95\%를 승화시키는 구간이며, 탈습건조는 결합 수를 제거하는 구간으로 수분 제거량은 적지만 승화건조기 간과 비슷한 시간이 소요되는 것으로 알려져 있다(27). 동결 건조 초기에는 피건조물의 열전달 저항과 응축기로의 물질 유속저항이 적기 때문에 건조속도가 빠르지만, 건조가 진 행되면서 건조층이 다공성으로 되어 열유속에 단열효과를 형성하며 주위에 높은 물질저항을 갖게 된다(27). 이러한 열과 물질전달 그리고 다른 인자들에 의한 저항 증가에 의해서 동결건조의 건조속도가 열풍건조와 진공건조보다 느린 것으로 보고되어 있다. 또한 열풍 및 진공건조 시 수분 의 증발속도보다 동결건조 시 수분의 기화속도가 느리다고 보고되었다(28).

\section{건조방법에 따른 총 페놀 및 플라보노이드 함량과 항산화 활성}

건조방법에 따른 눈개승마 건조물의 총 페놀 및 플라보 노이드 함량과 항산화 활성을 측정한 결과는 Fig. 4와 같다. 건조방법으로는 동결건조, 열풍건조, 진공건조를 실시하였 으며, 각각의 최종 건조물을 이용하여 총 페놀 및 플라보노 이드 함량과 항산화 활성을 비교하였다. 동결, 열풍, 진공건 조한 눈개승마의 총 페놀 함량은 각각 $40.72,68.78,108.75$ $\mathrm{GAE} \mathrm{g} / \mathrm{kg}$ 으로 나타났으며, 총 플라보노이드 함량은 각각 $16.15,22.55,34.77 \mathrm{RAE} \mathrm{g} / \mathrm{kg}$ 으로 나타나 진공건조, 열풍건 조, 동결건조 순으로 그 함량이 높았다. 또한 항산화 활성 측정을 위한 $\mathrm{DPPH}$ 라디컬 소거능, $\mathrm{ABTS}$ 라디컬 소거능, FRAP 분석 결과 모든 분석법에서 총 페놀 및 플라보노이드 함량의 결과와 일치하는 것으로 나타났다. Stewart 등(29)은 열처리 시 페놀 화합물의 증가는 조직 등과 결합되어 있는 결합형 페놀 화합물이 분리되어 유리형으로 전환되었기 때문으로 보고하였다. 대부분의 과채류에서 일어나는 효소 적 갈변은 폴리페놀 화합물이 공기 중의 산소와 polyphenol oxidase에 의해 quinone류나 그 유도체로 산화하는 반응으 로, 식품의 변색과 산화로 인한 품질 저하를 일으키는 주요 한 요인 중 하나이다(30). 따라서 진공건조의 경우 산소 농도가 낮은 환경에서 건조를 실시함으로써 유리형 페놀성 화합물의 산화 반응이 제어됨에 따라 가장 우수한 총 페놀 및 플라보노이드 함량과 항산화 활성을 가지는 것으로 생각 
(A)

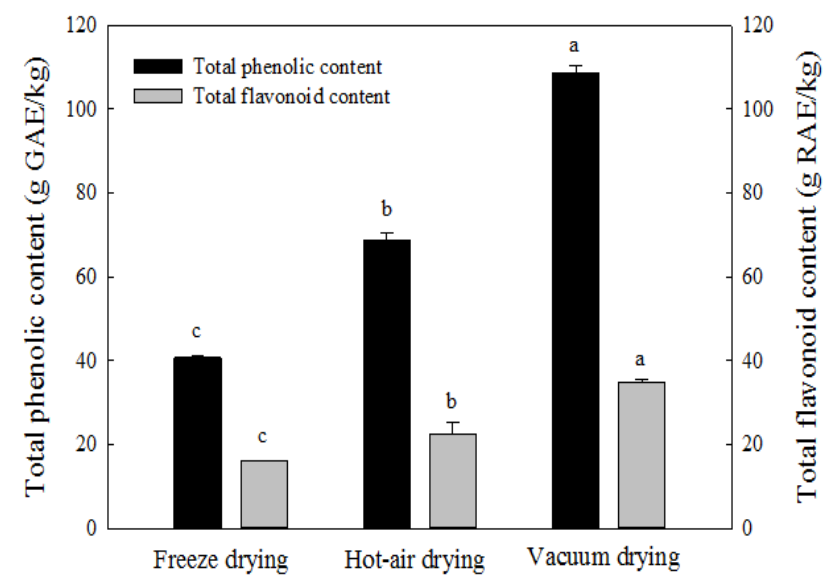

(B)

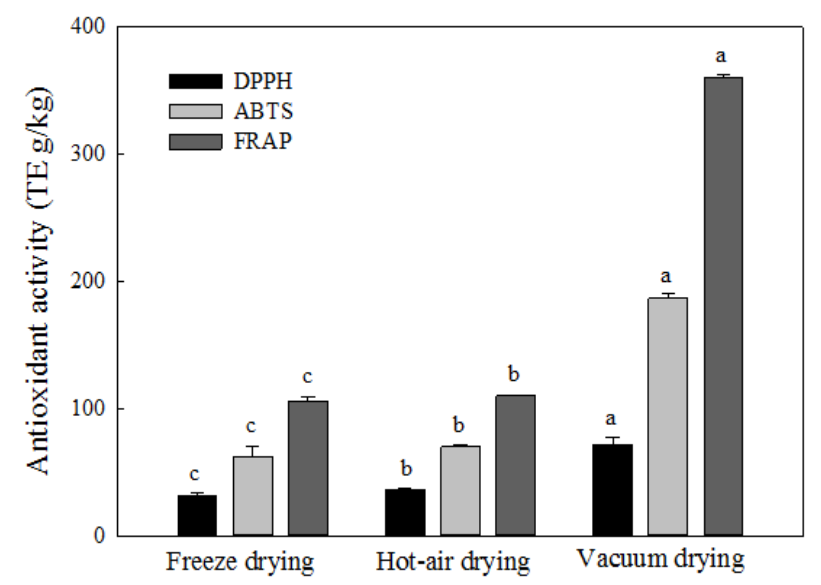

Fig. 4. Total phenolic and flavonoid content (A) and antioxidant activity such as DPPH radical scavenging activity, ABTS radical scavenging activity, and FRAP assay (B) of dried Aruncus dioicus var. kamtschaticus by different drying methods such as freeze, hot-air, and vacuum drying.

Results shown are mean $\pm \mathrm{SD}(\mathrm{n}=6)$. Different superscripts within the same parameter are significantly different $(\mathrm{p}<0.05)$ by Duncan's test.

된다. 반면, 본 연구와 달리 여러 연구결과에서 열풍, 진공 및 동결건조의 방법으로 식품건조물을 제조하였을 때 총 페놀 함량 및 항산화 활성이 동결, 진공 및 열풍건조 순으로 높다고 보고하였다(31,32). 이러한 상반된 결과는 피건조물
및 건조 조건의 차이에 기인한 것으로 생각된다. 특히 열풍 및 진공건조 시 최적 건조온도인 $100^{\circ} \mathrm{C}$ 에서 단시간 건조를 실시한 본 연구와 달리, 보고된 연구에서는 통상적으로 사 용하는 건조온도인 $50-60^{\circ} \mathrm{C}$ 에서 장시간 건조를 실시하였기 때문에, 서로 다른 연구결과가 도출된 것으로 생각된다.

\section{건조방법에 따른 건조특성}

건조방법에 따른 눈개승마 건조물의 건조특성을 알아보 기 위해 수분함량, 수분활성도, 수분용해지수 및 수분흡착 지수, 수화율을 분석하였으며, 그 결과는 Table 1 과 같다. 건조 전 눈개승마의 수분함량은 $76.09 \%$ 로 나타났으며, 진 공건조, 열풍건조, 동결건조 순으로 수분함량이 낮은 것으 로 나타났다. 각 건조방법별 건조무게가 항량이 될 때까지 건조를 완료시킨 경우에도 수분이 완전히 제거된 것은 아니 며, 모든 수분제거를 위해 건조된 시료의 수분함량을 $105^{\circ} \mathrm{C}$ 에서 수분정량을 실시하게 된다. 열 풍건조와 진공건조의 최적 건조온도인 $100^{\circ} \mathrm{C}$ 는 수분정량 시 사용하는 온도와 유사하기 때문에 동결건조보다 열풍 및 진공건조의 건조효 율이 높은 것으로 생각된다. 또한 진공건조한 시료는 열풍 건조보다 초기 건조속도가 빠르기 때문에 수축현상이 적게 일어나고 다공성 구조를 가지고 있어 수분증발이 용이한 것으로 보고되었으며, 이에 따라 진공건조한 시료의 수분 함량이 가장 낮은 것으로 생각된다 $(32,33)$. 건조 전 수분활 성도는 0.75 로 나타났으며, 건조방법에 따른 눈개승마의 수분활성도는 0.47-0.48로 유의적인 차이가 없었다. 수분용 해지수의 경우 건조방법에 따른 유의적인 차이가 없었으 며, 수분흡착지수와 복원성은 동결건조, 진공건조, 열풍건 조 순으로 높은 것으로 나타났다. Ha 등(28)과 Lee 등(33)은 건조방법에 따른 식품의 물리적 특성을 연구한 결과, 재수 화 특성의 경우 동결건조, 진공건조, 열풍건조 순으로 높다 고 보고하였다. Koh 등(32)은 동결건조, 진공건조, 열풍건 조 순으로 건조물의 공극률이 크고 밀도가 작은 것으로 나타났으며, 공극률이 클수록 흡습량이 높아진다고 보고하 였다. 동결건조와 진공건조는 피건조물의 다공성 구조를 가지게 하며, 건조 동안에 수축현상이 적고, 수분흡착력과 수화 복원성이 우수한 것으로 알려져 있다(32).

Table 1. Moisture content, water activity, water soluble index (WSI), water absorption index (WAI), and rehydration ratio of Aruncus dioicus var. kamtschaticus dried by hot-air drying and vacuum drying at $100^{\circ} \mathrm{C}$ and freeze drying

\begin{tabular}{cccccc}
\hline Drying methods & Moisture content $(\%)$ & Water activity & WSI (\%) & WAI (\%) & $\begin{array}{c}\text { Rehydration ratio } \\
(\mathrm{g} / \mathrm{g})\end{array}$ \\
\hline Freeze drying & $7.73 \pm 0.20^{1 / \mathrm{d} 2)}$ & $0.48 \pm 0.03^{\mathrm{a}}$ & $9.85 \pm 0.34^{\mathrm{a}}$ & $903.97 \pm 0.46^{\mathrm{a}}$ & $2.80 \pm 0.09^{\mathrm{a}}$ \\
Hot-air drying & $6.04 \pm 0.20^{\mathrm{b}}$ & $0.48 \pm 0.02^{\mathrm{a}}$ & $6.86 \pm 1.28^{\mathrm{a}}$ & $844.87 \pm 0.44^{\mathrm{c}}$ & $2.40 \pm 0.17^{\mathrm{b}}$ \\
Vacuum drying & $5.20 \pm 0.20^{\mathrm{c}}$ & $0.47 \pm 0.01^{\mathrm{a}}$ & $7.69 \pm 1.48^{\mathrm{a}}$ & $868.58 \pm 0.20^{\mathrm{b}}$ & $2.59 \pm 0.17^{\mathrm{ab}}$ \\
\hline
\end{tabular}

${ }^{1)}$ All values are mean $\pm \mathrm{SD}(\mathrm{n}=6)$.

${ }^{2}$ Different letters superscript indicate in the same column that means are significantly different $(\mathrm{p}<0.05)$ by Duncan's multiple range test. 


\section{요 약}

본 연구는 대표적인 산채식물인 눈개승마(삼나물)를 건 조물로 가공함으로써 저장성을 향상시킴과 동시에 체계적 인 건조방법 및 조건을 연구하여 고품질의 눈개승마 건조물 을 제조하고자 하였다. 이를 위해 현재 농가 및 산업체에서 주로 이용하고 있는 건조법인 열풍, 진공, 동결건조방법에 따른 눈개승마의 건조곡선을 통하여 최종 건조조건을 설정 하였고, 각 건조방법이 품질 특성에 미치는 영향을 알아보 았다. 건조방법에 따라 처리한 건조물의 영양적 특성으로 총 페놀 및 플라보노이드 함량과 항산화 활성을 측정하였으 며, 건조특성으로 수분함량, 수분활성도, 수분용해지수, 수 분흡착지수, 수화복원성을 분석하여 비교하였다. 그 결과 최종 건조조건으로는 열풍건조와 진공건조는 모두 건조온 도 $100^{\circ} \mathrm{C}$, 건조시간 10 분, 동결건조의 경우 건조시간 210 분 으로 나타났으며, 최종 평형수분함량은 각각 $6.04,5.20$, $7.73 \%$ 으로 나타났다. 또한 수분활성도와 수분용해지수는 건조방법에 따른 유의적인 차이가 없었으며, 수분용해지수 와 수화복원성은 동결건조, 진공건조, 열풍건조 순으로 높 게 나타났다. 건조방법에 따른 눈개승마의 총 페놀 및 플라 보노이드 함량과 항산화 활성을 측정한 결과, 진공건조, 열풍건조, 동결건조 순으로 함량 및 활성이 높은 것으로 나타났다. 결과적으로 눈개승마를 건조하였을 때, 동결건 조는 가장 높은 건조특성을 부여하는 것으로 나타났으며, 진공건조는 건조특성 향상과 동시에 우수한 생리활성능을 가지는 건조 눈개승마를 제조할 수 있는 건조방법으로 판단 되었다. 따라서 본 연구결과는 고품질의 건조 눈개승마를 가공함과 동시에 건조 산채류 제조 시 기초자료로 활용될 수 있을 것으로 생각된다.

\section{감사의 글}

본 논문은 산림청(한국임업진흥원) 산림과학기술 연구 개발사업‘2017028A00-1720-BA01)’의 지원에 의하여 이루 어진 것입니다.

\section{References}

1. Youn JS, Shin SY, Wu Y, Hwang JY, Cho JH, Ha YG, Kim JK, Park MJ, Lee S, Kim TH, Kim T (2012) Antioxidant and anti-wrinkling effects of Aruncus dioicus var. kamtschaticus extract. Korean J Food Preserv, 19, 393-399

2. Kim MS, Kim KH, Jo JE, Choi JJ, Kim YJ, Kim JH, Jang SA, Yook HS (2011) Antioxidative and antimicrobial activities of Aruncus dioicus var. kamtschaticus hara extracts. J Korean Soc Food Sci Nutr, 40, 47-55

3. Kim DH, Moon YS, An BJ, Son JH (2012) Potent anti-aging actiity of Aruncus dioicus, a native plant of Ulleung-do, South Korea, in CCD-986sk fibroblasts via suppression of matrix metalloproteinases. J Nat Med, 66, 631-636

4. Zhang Q, Kim HY (2014) DNA damage protection and anti-inflammatory activity of different solvent fractions from Aruncus dioicus var. kamtschaticus. Korean J Plant Res, 27, 714-719

5. Shin JW, Lee SI, Woo MH, Kim SD (2008) Effect of ethanol extracts of goat's beard on streptozotocin induced diabetic symptoms and oxidative stress in rats. J East Asian Soc Dietary Life, 18, 939-948

6. Ahn H, Kim J, Kim J, Auh J, Choe E (2014) In vitro a-glucosidase and pancreatic lipase inhibitory activities and antioxidants of Samnamul (Aruncus dioicus) during rehydration and cooking. Food Sci Biotechnol, 23, 1287-1293

7. Kim EM (2016) Processing materials of edible wild herbs and vegetables. Food Science and Industry, 49, 63-70

8. Hong JH, Lee WY (2004) Quality characteristics of osmotic dehydrated sweet pumpkin by different drying methods. J Korean Soc Food Sci Nutr, 33, 1573-1579

9. Hwang KT, Rhim JW (1994) Effect of various pretreatments and drying methods on the quality of dried vegetables. Korean J Food Sci Technol, 26, 805-813

10. Lee JH, Kim HJ (2008) Vacuum drying kinetics of Asian white radish (Raphanus stivus L.) slices. LWT-Food Sci Tehcnol, 42, 180-186

11. Irzyniec Z, Klimczak J, Michalowski S (1995) Freeze-drying of the black currant juice. Drying Technol, $13,417-424$

12. AOAC (1995) Official Methods of Analysis. $16^{\text {th }}$ ed, Association of Official Analytical Chemists, Washington DC, USA, p 4.1-4.17

13. Kim DO, Jeong SW, Lee CY (2003) Antioxidant capacity of phenolic phytochemicals from various cultivars of plums. Food Chem, 81, 321-326

14. Chae SK, Kang GS, Ma SJ, Bang KW, Oh MW, Oh SH (2002) Standard Food Anlaysis. Jigu Publishing Co, Seoul, Korea, p 381-382

15. Blois MA (1958) Antioxidant determinations by the use of a stable free radical. Nature, 181, 1199-1200

16. Re R, Pellegrini N, Proteggente A, Pannala A, Yang M, 
Rice-Evans C (1999) Antioxidant activity applying an improved ABTS radical cation decolorization assay. Free Radical Bio Med, 26, 1231-1237

17. Benzie IFF, Strain JJ (1996) The ferric reducing ability of plasma (FRAP) as a measure of "antioxidant power": the FRAP assay. Anal Biochem, 239, 70-76

18. AACC (1983) Approved Method of the AACC. $10^{\text {th }}$ ed, American Association of Cereal Chemists, St Paul, MN, USA, p 56-20

19. Koh S, Rhim JW, Kim JM (2011) Effect of freezing temperature on the rehydration properties of freeze-dried rice porridge. Korean J Food Sci Technol, 43, 509-512

20. Rhim JW, Hwang KT (1995) Study on the drying characteristics of wild vegetables. Korean J Food Sci Technol, 27, 358-364

21. Lee SO, Lee HJ, Yu MH, Im HG, Lee IS (2005) Total polyphenol contents and antioxidant activities of methanol extracts from vegetables produced in Ullung Island. Korean J Food Sci Technol, 37, 233-240

22. Park SB, Lee U, Kang JY, Kim JM, Park SK, Park SH, Choi SG, Heo HJ (2017) Protective effects of Aruncus dioicus var. kamtschaticus extract against hyperglycemicinduced neurotoxicity. Korean J Food Sci Technol, 49, 668-675

23. Suh JT, Choi EY, Yoo DL, Kim KD, Lee JN, Hong SY, Kim SJ, Nam JH, Han HM, Kim MJ (2015) Comparative study of biological activities at different harvesting times and new varieties for highland culture of gomchwi. Korean J Plant Res, 28, 391-399

24. Choi Y, Lee SM, Chun J, Lee HB, Lee J (2006) Influence of heat treatment on the antioxidant activities and polyphenolic compounds of shiitake (Lentinus edodes) mushroom. Food Chem, 99, 381-387

25. Kim JW, Lee SH, No HK, Hong JH, Park CS, Youn KS (2013) Effects of pretreatment and drying methods on quality and antioxidant activities of dried jujube
(Zizyphus jujuba) fruit. J Korean Soc Food Sci Nutr, 42, $1242-1248$

26. Lee SH, Song EM, Jang GY, Li M, Kim MY, Park HJ, Kang TS, Jeong HS (2013) Physicochemical characteristics and antioxidant activities of Doragi (Platycodon grandiflorum) at different aging temaperatures and for various durations. J Korean Soc Food Sci Nutr, 42, 1405-1411

27. Park NH, Bae SC (1993) Prediction of the drying time under the various operational conditions using a sublimation model. Trans Korean Soc Mech Eng, 17, 2088-2098

28. Ha YS, Park JW, Lee JH (2001) Physical characteristics of mushroom (Agaricus bisporus) as influenced by different drying methods. Korean J Food Sci Technol, 33, 245-251

29. Stewart AJ, Bozonnet S, Mullen W, Jenkins GI, Lean MEJ, Crozier A (2000) Occurrence of flavonols in tomatoes and tomato-based products. J Agric Food Chem, 48, 2663-2669

30. Rivas NDJ, Whitaker JR (1973) Purification and properties of two polyphenol oxidases from bartlett pears. Plant physiol, 52, 501-507

31. Park SJ, Choi YB, Ko JR, Rha YA, Lee HY (2014) Effects of drying methods on the quality and physiological activities of blueberry (Vaccinium ashe1). Korean J Food Cook Sci, 20, 55-64

32. Koh JW, Lee WY, Lee JH, Ha YS, Choi YH (1999) Absorption characteristics of dried shiitake mushroom powder suing different drying methods. Korean J Food Sci Technol, 31, 128-137

33. Lee KS, Park KH, Lee SH, Choe EO, Lee HG (2003) The quality properties of dried carrots as affected by blanching and drying methods during storage. Korean J Food Sci Technol, 35, 1086-1092 